\title{
DEMOKRASI LIBERAL
}

DEFA NUR IFADA FAUZI

IIK STRADA INDONESIA

Defaifada2002@gmail.com

\begin{abstract}
ABSTRAK
Demokrasi liberal (atau demokrasi konstitusional) adalah sistem politik yang menganut kebebasan individu.
\end{abstract}

Secara konstitusional, ini dapat diartikan sebagai hak-hak individu dari kekuasaan pemerintah.[1] Dalam demokrasi liberal, keputusan-keputusan mayoritas (dari proses perwakilan atau langsung) diberlakukan pada sebagian besar bidang-bidang kebijakan pemerintah yang tunduk pada pembatasan-pembatasan agar keputusan pemerintah tidak melanggar kemerdekaan dan hak-hak individu seperti tercantum dalam konstitusi.[2][3]

Demokrasi liberal pertama kali dikemukakan pada Abad Pencerahan oleh penggagas teori kontrak sosial seperti Thomas Hobbes, John Locke, dan Jean-Jacques Rousseau. Semasa Perang Dingin, istilah demokrasi liberal bertolak belakang dengan komunisme ala Republik Rakyat. Pada zaman sekarang demokrasi konstitusional umumnya dibanding-bandingkan dengan demokrasi langsung atau demokrasi partisipasi

\section{LATAR BELAKANG}

Setelah dibubarkannya RIS, sejak tahun 1950 RI melaksanakan demokrasi parlementer yang lebih Liberal dengan mencontoh sistem parlementer barat, dan masa ini disebut Masa demokrasi Liberal. Indonesia dibagi manjadi 10 Provinsi yang mempunyai otonomi dan berdasarkan Undang-undang Dasar Sementara tahun 1950. Akibat pelaksanaan konstitusi tersebut, pemerintahan RI dijalankan oleh suatu dewan menteri (kabinet) yang dipimpin oleh seorang perdana menteri dan bertanggung jawab kepada parlemen (DPR).

Sistem politik pada masa demokrasi liberal mendorong lahirnya partai- partai politik, karena dalam sistem kepartaian menganut sistem multi partai. Konsekuensi logis dari pelaksanaan sistem politik demokrasi liberal parlementer gaya barat dengan sistem multi partai yang dianut, maka partai -partai inilah yang menjalankan pemerintahan melalui perimbangan kekuasaan dalam parlemen dalam tahun 1950-1959. 
Kurun waktu antara tahun 1950 sampai dengan tahun 1959 merupakan masa berkiprahnya partai-partai politik pada pemerintahan Indonesia. Pada masa ini terjadi pergantian kabinet, partai-partai politik terkuat mengambil alih kekuasaan. PNI dan Masyumi merupakan partai yang terkuat dalam DPR, dan dalam waktu lima tahun (1950-1955) PNI dan Masyumi silih berganti memegang kekuasaan dalam empat kabinet.

Sistem multi partai adalah salah satu varian dari beberapa sistem kepartaian yang berkembang di dunia modern saat ini. Kata kunci dari sistem multipartai tersebut adalah jumlah partai politik yang tumbuh atau eksis yang mengikuti kompetisi mendapatkan kekuasaan melalui pemilu, lebih dari dua partai politik.

Umumnya sistem ini dianggap cara paling efektif dalam merepresentasikan keinginan rakyat yang beranekaragam ras, agama, atau suku. Dan lebih cocok dengan pluralitas budaya dan politik di banding dwi partai. Sistem ini dalam kepemerintahan parlementer cenderung menitikberatkan kekuasaan pada badan legislatif, hingga badan eksekutif sering berperan lemah dan ragu-ragu. Sebab tidak ada satu partai yang cukup kuat untuk menduduki kepemerintahan sendiri hingga memaksa untuk berkoalisi.

Selama kurun waktu 1950-1959 sering kali terjadi pergantian kabinet yang menyebabkan instabilitas politik. Parlemen mudah mengeluarkan mosi tidak percaya terhadap kabinet sehingga koalisi partai yang ada di kabinet menarik diri dan kabinet pun jatuh. Sementara Sukarno selaku Presiden tidak memiliki kekuasaan secara riil kecuali menunjuk para formatur untuk membentuk kabinet- kabinet baru, suatu tugas yang sering kali melibatkan negosiasi-negosiasi yang rumit. Kabinet Koalisi yang diharapkan dapat memperkuat posisi kabinet dan dapat didukung penuh oleh partai-partai di parlemen ternyata tidak mengurangi panasnya persaingan perebutan kekuasaan antar elite politik.

2

Demokrasi liberal adalah salah satu bentuk sistem pemerintahan yang diselenggarakan secara bebas yang mengakui hak-hak indivdu secara asbsolut. Demokrasi liberal berarti demokrasi yang di kembangkan dari sistem demokrasi yang sesungguhnya.

Istilah Demokrasi Liberal mulai muncul dan di kenal setelah Perang Dunia Ke-II yang menjadikan dunia terbelah atas kutub Barat dan Timur. Kutub timur lebih merepresentatifkan komunisme, sedangkan kutub Barat diwakili oleh paham liberal dengan istilah demokrasi liberal. Demokrasi Liberal lebih menekankan pada pengakuan terhadap hak-hak warga negara, baik sebagai individu maupun masyarakat. Dan karenanya lebih bertujuan menjaga tingkat representasi warga negara dan melindunginya dari tindakan kelompok atau negara lain. 


\section{RUMUSAN MASALAH}

Indonesia setidaknya telah melalui empat masa demokrasi dengan berbagai versi. Pertama adalah demokrasi liberal atau parlementer di masa awal kemerdekaan. Kedua adalah demokrasi terpimpin, ketika Presiden Soekarno membubarkan konstituante dan mendeklarasikan demokrasi terpimpin. Ketiga adalah demokrasi Pancasila yang dimulai sejak pemerintahan Presiden Soeharto. Keempat adalah demokrasi yang saat ini masih dalam masa transisi. Kelebihan dan kekurangan pada masing-masing masa demokrasi tersebut pada dasarnya bisa memberikan pelajaran berharga bagi bangsa Indonesia.

Demokrasi parlementer yang berlaku pada periode (1945-1959) ternyata belum bisa memberikan perubahan berarti bagi Indonesia. Demokrasi parlementer yang dikemudian hari disebut sebagai demokrasi liberal karena rakyat benar-benar diberikan kebebasan seluas-luasnya untuk berpolitik bahkan untuk membentuk partai sekalipun. Juga pada waktu demokrasi liberal setiap anggota kabinet berhak mengajukan mosi tidak percaya kepada pemerintah. Dan oleh presiden Soekarno demokrasi ini dianggap sebagai demokrasi cara Barat karena menimbulkan perpecahan nasional, akhirnya diganti dengan demokrasi terpimpin.

Sementara demokrasi Pancasila yang lahir setelah tumbangnya demokrasi terpimpin dan dimulainya Orde Baru tahun 1966. Oleh rezim Orde Baru demokrasi Pancasila ini dianggap sebagai koreksi total terhadap sistem-sistem

demokrasi yang "menyimpang" dalam masa-masa sebelumnya. Stabilitas keamanan sangat dijaga sehingga terjadi pemasungan kebebasan berbicara. Namun tingkat kehidupan ekonomi rakyat relatif baik. Hal ini juga tidak terlepas dari sistem nilai tukar dan alokasi subsidi BBM sehingga harga-harga barang dan jasa berada pada titik keterjangkauan masyarakat secara umum. Namun demikian penyakit korupsi, kolusi dan nepotisme (KKN) semakin parah menjangkiti pemerintahan. Lembaga pemerintahan yang ada di legislatif, eksekutif dan yudikatif terkena virus KKN ini.

Di sisi lain, situasi politik selama 32 tahun di bawah rezim Demokrasi Pancasila, rakyat semakin merasa hak-hak politiknya dipasung. Pemberlakuan Undang-undang Anti Subversi dan pembatasan kebebasan pers yang terlalu ketat. telah dirasakan menyumbat kran demokrasi. Demokrasi Pancasila pun menemui kegagalannya dan berakhir.

Bersamaan dengan kompetisi dunia menumbuhkan kembali semangat demokratisasi. Pengalaman sejarah mengajak Indonesia mencoba menggunakan "Demokrasi terbuka". Tahun 1998 merupakan babak keempat sejarah demokrasi di Indonesia dimulai, sebuah transisi demokrasi.

Menerapkan demokrasi terbuka untuk realitas Indonesia sesungguhnya merupakan perhitungan politik yang cukup berani, mengingat rakyat pada umumnya belum memahami secara memadai apa itu demokrasi. Demokrasi berjalan tanpa arah dan tidak ada yang mampu mengendalikan. Masing-masing kelompok menyuarakan demokrasi berdasarkan kepentingannya sendiri (Kholid O. Santoso, 2006 : 11). 
Di tengah demokrasi "terbuka" kondisi Indonesia semakin ambruk di semua sektor kehidupan. Kali ini penyelenggaran demokrasi gagal karena tidak saja tidak dapat membendung. kecenderungan rezim penguasa, tetapi juga terlalu hanyut dalam emosi massa rakyat. Semua itu telah membuat kenyataan pahit bahwa pelaksanaan demokrasi di Indonesia tidak seindah ketika demoktrasi itu diteorikan.

Selain dari konsep demokrasi di atas, ada satu konsep demokrasi lagi di Indonesia yang belum pernah dilaksanakan. Yaitu konsep demokrasi Muhammad. Hatta. Atau yang lebih popular dengan sebutan Bung Hatta. Menurut Bung Hatta (2008:122) Negara Indonesia haruslah berbentuk Republik berdasarkan kedaulatan rakyat. Kedaulatan rakyat yang dipahamkan harus bersifat kolektivisme bukan individualisme seperti yang dipropagandakan J.J Roesseau. Kedaualtan rakyat tidak cukup hanya dibidang politik, tapi juga di bidang ekonomi dan sosial. Kalau tidak seperti itu kedaulatan belum tercapai karena belum ada persamaan dan persaudaraan. Oleh sebab itu, cita-cita demokrasi Indonesia ialah demokrasi sosial, meliputi seluruh lingkungan hidup yang menentukan nasib manusia. Dan semangat demokrasi Indonesia ialah demokrasi sosial dan kolektif. Dalam implementasinya Bung Hatta menjabarkan, untuk bidang politik dilaksanakan sistem perwakilan rakyat dengan musyawarah, berdasarkan kepentingan umum. Dalam segi ekonomi semangat gotong royong yang merupakan koperasi sebagai dasar perekonomian rakyat. Dalam segi sosial diadakan jaminan untuk perkembangan kepribadian manusia. Manusia bahagia sejahtera menjadi tujuan bernegara.

\section{PEMBAHASAN}

Kata Demokrasi berasal dari Yunani, yaitu demos, yang berarti rakyat, dan kratos, yang berarti pemerintahan atau kekuasaan. Jadi demokrasi ialah rakyat yang berkuasa.

Setelah Perang Dunia ke-II, secara formal demokrasi merupakan dasar dari kebanyakan negara di dunia. Di antara semakin banyak aliran pemikiran yang menamakan dirinya sebagai demokrasi, ada dua aliran penting, yaitu demokrasi konstitusional dan kelompok yang mengatasnamakan dirinya "demokrasi" namun pada dasarnya menyandarkan dirinya pada komunisme.

Demokrasi yang dianut di Indonesia, yaitu demokrasi berdasarkan Pancasila, masih dalam taraf perkembangan. Dan mengenai sifat dan cirinya masih terdapat pelbagai tafsiran serta pandangan. Pada perkembangannya, sebelum berdasarkan pada demokrasi pancasila, Indonesia mengalami tiga periodeisasi penerapan demokrasi, yaitu: 
Demokrasi Liberal ( 1950-1959 )

Demokrasi Terpimpin ( 1959-1966)

Demokrasi Pancasila ( 1966-sekarang)

Demokrasi liberal (atau demokrasi konstitusionnal) adalah sistem politik yang menganut kebebasan individu. Secara konstitusional hak-hak individu dari kekuasaan pemerintah. Dalam demokrasi liberal, keputusan-keputusan mayoritas (dari proses perwakilan atau langsung) diberlakukan pada sebagian besar bidang-bidang kebijakan pemerintah yang tunduk pada pembatasan-pembatasan agar keputusan pemerintah tidak melanggar kemerdekaan dan hak-hak individu seperti tercantum dalam konstitusi.

Baca Juga Artikel yang Mungkin Berkaitan : Demokrasi - Pengertian, Macam, Prinsip, Ciri, Sejarah Dan Contohnya

recommended by

Mgid

Mgid

HEMONIX

Lupakan Wasir! Cari Tahu Cara Menghilangkannya Hari Ini!

PELAJARI LEBIH

Demokrasi liberal pertama kali dikemukakan pada Abad Pencerahan oleh penggagas teori kontrak sosial seperti Thomas Hobbes, John Locke, dan Jean-Jacques Rousseau. Semasa Perang Dingin, istilah demokrasi liberal bertolak belakang dengan komunisme ala Republik Rakyat. Pada zaman sekarang demokrasi konstitusional umumnya dibanding-bandingkan dengan demokrasi langsung atau demokrasi partisipasi.

Demokrasi liberal dipakai untuk menjelaskan sistem politik dan demokrasi barat di Amerika Serikat, Britania Raya, Kanada. Konstitusi yang dipakai dapat berupa republik (Amerika Serikat, India, Perancis) atau monarki konstitusional (Britania Raya, Spanyol). 
Demokrasi liberal dipakai oleh negara yang menganut sistem presidensial (Amerika Serikat), sistem parlementer (sistem Westminster: Britania Raya dan Negara-Negara Persemakmuran) atau sistem semipresidensial (Perancis)

\section{KESIMPULAN}

Demokrasi liberal adalah salah satu bentuk sistem pemerintahan yang berkiblat pada demokrasi. Demokrasi liberal berarti demokrasi yang liberal. Liberal disini dalam artian perwakilan atau representatif.

Dengan pelaksanaan konstitusi tersebut, pemerintahan Republik Indonesia dijalankan oleh suatu dewan menteri (kabinet) yang dipimpin oleh seorang perdana menteri dan bertanggung jawab kepada parlemen (DPR). Sistem multi partai pada masa demokrasi liberal mendorong untuk lahirnya banyak partai-partai politik dengan ragam ideologi dan tujuan politik.

Demokrasi Liberal sendiri berlangsung selama hampir 9 tahun, dalam kenyataanya bahwa UUDS 1950 dengan sisten Demokrasi Liberal tidak cocok dan tidak sesuai dengan kehidupan politik bangsa Indonesia yang majemuk.

pada akhir tahun 1956, situasi tanah air ditandai dengan pelbagai macam instabilitas politik, pergolakan daerah dan gejolak didalam angkatan perang. Dan akhirnya terjadi pula kemacetan di dalam konstituante. Pergolakan-pergolakan ini

66

adalah akibat daripada gagalnya sistem demokrasi liberal. Partai-partai politik terus menerus saling berebut pengaruh dan berebut rezeki, tanpa memikirkan kepentingan rakyat. Mereka melakukan pelbagai tipu muslihat atau akal-akalan dalam usaha mencapai maksudnya, memenangkan kepntingan partainya., bahkan ada partai yang tidak segan-segan menjatuhkan kabinet yang perdana menterinya anggota sendiri. Dengan demikian stabilitas politik tidak mungkin tercapai

Untuk menembus jalan buntu itu presiden Soekarno mengusulkan suatu gagasan. Gagasan Presiden ini dilontarkan oleh Presiden tanpa sepengetahuan kabinet. Presiden Soekarno, meskipun formalnya adalah Presiden konstitusional, bertindak selaku pemimpin rakyat yang prihatin karena kekacauan politik yang memuncak, sehingga bisa membahayakan keutuhan bangsa dan negara. Pada tanggal 21 februari 1957, dihadapan para pemimpin partai dan tokoh masyarakat di Jakarta, presiden Soekarno mengemukakan gagasannya yang kemudian terkenal sebagai Konsepsi Presiden, yang berkisar pada kabinet yang dinamakannya Kabinet Gotong-Royong dan dewan yang dinamakannya Dewan Nasional dibawah pimpinannya.

Pokok-pokok isi konsepsi Presiden itu adalah: 
1) Sistem Demokrasi Parlementer secara Barat tidak sesuai dengan kepribadian Indonesia, oleh karena itu harus diganti dengan sistem Demokrasi Terpimpin

2) Untuk pelaksanaan sistem Demokrasi Terpimpin perlu dibentuk suatu Kabinet Gotong-Royong yang anggota-anggotanya terdiri dari semua

67

partai dan organisasi berdasarkan perimbangan kekuatan yang ada dalam masyarakat. Konsepsi Presiden ini mengetengahkan pula perlunya pembentukan "Kabinet Kaki Empat" yang mengandung arti bahwa, empat partai besar, tidak hanya PNI, Masyumi dan NU melainkan juga PKI, harus turut serta didalamnya untuk menciptakan kegotong-royongan nasional.

3) Pembentukan Dewan Nasional yang terdiri dari golongan fungsional dalam masyarakat. Dewan Nasional ini tugas utamanya adalah memberi nasihat kepada Kabinet, baik diminta maupun tidak diminta.

Pada tanggal 5 Juli 1959 Presiden Soekarno mengumumkan dekrit presiden mengenai pembubaran Dewan Konstituante dan berlakunya kembali UUD 1945 serta tidak berlakunya UUDS 1950 karena dianggap tidak cocok dengan keadaan ketatanegaraan Indonesia.

B. Saran

Dari hasil penelitian ini diharapkan dapat memberikan manfaat antara lain

1. Dalam upaya pengembangan materi dan pembahasan, diharapkan kepada peneliti selanjutnya yang akan meneliti mengenai materi yang bersangkutan

untuk lebih mengembangkan pembahasan dengan menambah literatur lain

2. Kepada para pembaca, disarankan disarankan untuk melakukan penelitian lanjutan mengenai Pengaruh Sistem Multipartai Pada Demokrasi Liberal

Terhadap Stabilitas Politik Indonesia 1950-1959

3. Sebagai bahan masukan untuk melakukan penelitian dan menyusun karya ilmiah.

\section{DAFTAR PUSTAKA}

Siyoto, S., \& Sodik, M. A. (2015). Dasar metodologi penelitian. Literasi Media Publishing. http://digilib.unimed.ac.id/29583/6/6.\%20NIM.\%203133321045\%20CHAPTER\%20I.pdf 
http://digilib.uinsgd.ac.id/2241/4/4_bab1.pdf

https://www.dosenpendidikan.co.id/pengertian-demokrasi-liberal/

http://digilib.unimed.ac.id/29583/2/10.\%20NIM.\%203133321045\%20CHAPTER\%20V.pdf 